\title{
Reactor Grout Thermal Properties
}

J. L. Steimke, Z. H. Qureshi, M. L. Restivo and H. N. Guerrero

January 2011

Savannah River National Laboratory Savannah River Nuclear Solutions Aiken, SC 29808

Prepared for the U.S. Department of Energy under contract number DE-AC09-08SR22470.

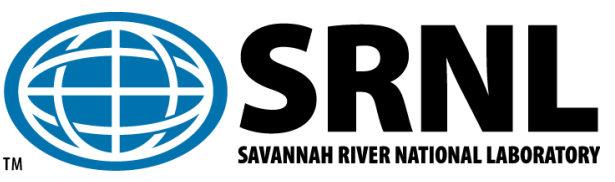


SRNL-STI-2010-00806

Revision 0

\section{DISCLAIMER}

This work was prepared under an agreement with and funded by the U.S. Government. Neither the U.S. Government or its employees, nor any of its contractors, subcontractors or their employees, makes any express or implied:

1. warranty or assumes any legal liability for the accuracy, completeness, or for the use or results of such use of any information, product, or process disclosed; or

2. representation that such use or results of such use would not infringe privately owned rights; or

3. endorsement or recommendation of any specifically identified commercial product, process, or service.

Any views and opinions of authors expressed in this work do not necessarily state or reflect those of the United States Government, or its contractors, or subcontractors.

\section{Printed in the United States of America \\ Prepared for \\ U.S. Department of Energy}


SRNL-STI-2010-00806

Revision 0

\section{REVIEWS AND APPROVALS}




\section{ACKNOWLEDGEMENTS}

Christine Langton and David Stefanko provided direction for this program. The program was funded through Economic Recovery and Reinvestment Act. 


\section{EXECUTIVE SUMMARY}

Savannah River Site has five dormant nuclear production reactors. Long term disposition will require filling some reactor buildings with grout up to ground level. Portland cement based grout will be used to fill the buildings with the exception of some reactor tanks. Some reactor tanks contain significant quantities of aluminum which could react with Portland cement based grout to form hydrogen. Hydrogen production is a safety concern and gas generation could also compromise the structural integrity of the grout pour. Therefore, it was necessary to develop a non-Portland cement grout to fill reactors that contain significant quantities of aluminum.

Grouts generate heat when they set, so the potential exists for large temperature increases in a large pour, which could compromise the integrity of the pour. The primary purpose of the testing reported here was to measure heat of hydration, specific heat, thermal conductivity and density of various reactor grouts under consideration so that these properties could be used to model transient heat transfer for different pouring strategies. A secondary purpose was to make qualitative judgments of grout pourability and hardened strength.

Some reactor grout formulations were unacceptable because they generated too much heat, or started setting too fast, or required too long to harden or were too weak. The formulation called $102 \mathrm{H}$ had the best combination of characteristics. It is a Calcium Alumino-Sulfate grout that contains Ciment Fondu (calcium aluminate cement), Plaster of Paris (calcium sulfate hemihydrate), sand, Class F fly ash, boric acid and small quantities of additives. This composition afforded about ten hours of working time. Heat release began at 12 hours and was complete by 24 hours. The adiabatic temperature rise was $54^{\circ} \mathrm{C}$ which was within specification. The final product was hard and displayed no visible segregation. The density and maximum particle size were within specification. 


\section{TABLE OF CONTENTS}

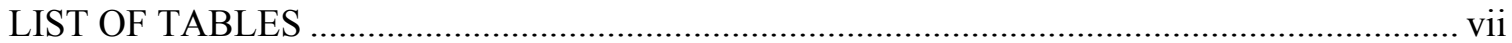

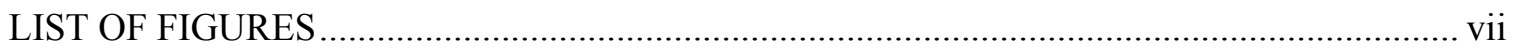

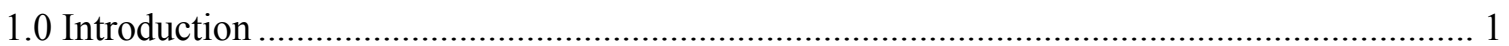

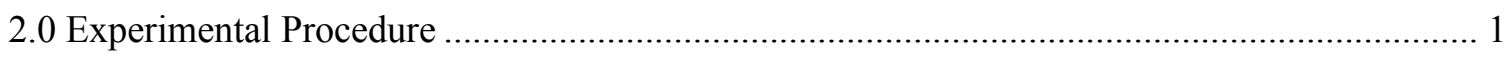

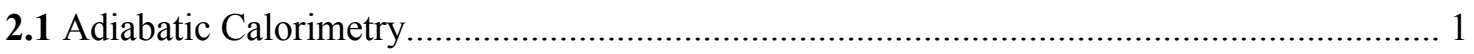

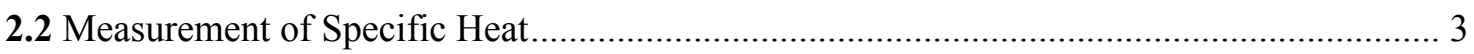

2.3 Measurement of Density and Thermal Conductivity ....................................................... 4

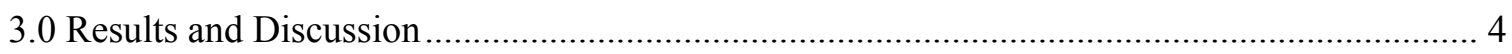

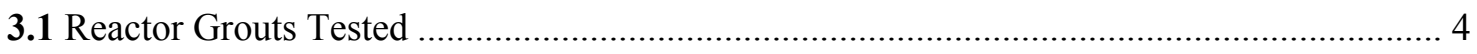

3.2 Results for Density, Thermal Conductivity and Specific Heat........................................... 6

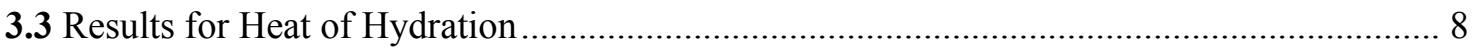

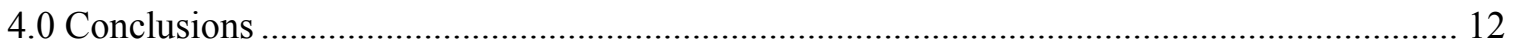

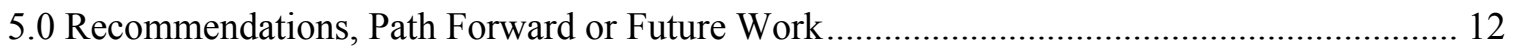

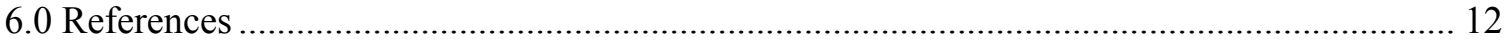




\section{LIST OF TABLES}

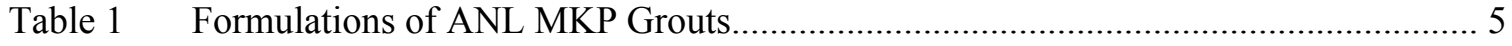

Table 2 Formulations of Pre-mixed (Bindan) Grouts................................................................. 5

Table 3 Formulations of Calcium Alumino-sulfate Grouts ................................................... 6

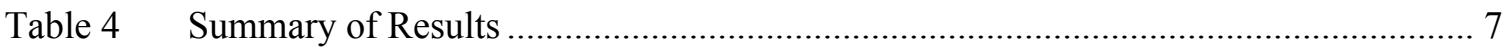

\section{LIST OF FIGURES}

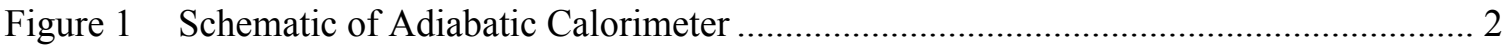

Figure 2 Transient Thermal Response of Short Cylinder ......................................................... 4

Figure 3 Calorimeter Temperatures for Pre-mixed MKP (Bindan) Grout................................ 8

Figure 4 Calorimeter Temperatures for ANL MKP Grouts................................................... 9

Figure 5 Calorimeter Temperatures for Calcium Sulfo-aluminate Grouts ............................... 9

Figure 6 Heat Generation for Calcium Sulfo-Aluminate Grouts............................................ 10

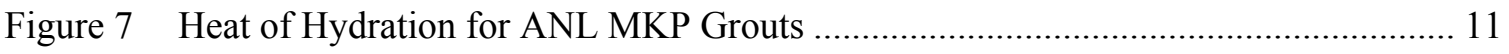

Figure 8 Heat of Hydration for Pre-mixed Bindan Formulations ............................................. 11

Figure 9 Heat of Hydration for Calcium Sulfo-aluminate Grouts .......................................... 12 


\section{LIST OF ABBREVIATIONS}

$\begin{array}{ll}\text { ANL } & \text { Argonne National Laboratory } \\ \text { MKP } & \text { Magnesium Potassium Phosphate grout } \\ \text { monoKP } & \text { Mono potassium phosphate } \\ \text { PID } & \text { Proportional integral differential } \\ \text { SRNL } & \text { Savannah River National Laboratory } \\ \text { SRS } & \text { Savannah River Site } \\ \text { TC } & \text { thermocouple } \\ \text { USH } & \text { Universal Sleeve Housing }\end{array}$




\subsection{Introduction}

Five nuclear reactors were built at Savannah River Site (SRS) in the 1950's to produce plutonium, tritium and other materials for nuclear weapons. Three years after the end of the Cold War the last of the five reactors had been shut down. Final disposition for some reactor buildings calls for filling the reactor building up to ground level with Portland cement based grout. SRS has much experience with Portland cement based grouts because decontaminated salt solution is disposed in large vaults as Saltstone, which is a mixture of salt solution, Portland cement, fly ash and furnace slag. Portland cement based grout can not be used to fill reactor vessels containing significant quantities of aluminum because a reaction forms hydrogen gas. The primary source of aluminum in reactors is Universal Sleeve Housings. As part of the selection of a suitable reactor grout it was necessary to measure heat of hydration and other thermal properties for candidate grouts. Steimke and Fowley [1998] measured these properties for Saltstone. Their methods, with minor modifications, were used in the current work.

Langton, et al. [2010] listed requirements for the P-Reactor grout which include

1. $\mathrm{pH}<10.5$

2. dynamic working time $>60$ minutes

3. $2 \mathrm{hr}<$ set time $<24$ hours

4. density $>80 \mathrm{lb} / \mathrm{ft}^{3} \quad\left(1282 \mathrm{~kg} / \mathrm{m}^{3}\right)$

5. no visible segregation

6. maximum particle size $<3 \mathrm{~mm}$

7. adiabatic temperature rise $<65^{\circ} \mathrm{C}$.

\subsection{Experimental Procedure}

The experimental procedures described by Steimke and Fowley [1998] were used and will be briefly summarized.

\subsection{Adiabatic Calorimetry}

There are two basic methods for measuring heat of reaction including heat of hydration, isothermal calorimetry and adiabatic calorimetry. In isothermal calorimetry the sample is maintained at constant temperature and the amount of heat flowing out of the sample is measured. In adiabatic calorimetry the sample is inserted in a stirred bath. The goal is to maintain the bath at the same temperature as the sample so that no heat flows between the sample and the bath. A differential thermocouple (TC) is used to measure the temperature difference between the sample and bath. One could independently measure sample temperature and bath temperature and subtract the two numbers, but a differential thermocouple is more accurate. Heat is added to the bath to drive the temperature difference to zero.

The adiabatic calorimeter is shown in Figure 1. The grout sample is poured into the sample dewar and half of the differential thermocouple and also the grout thermocouple are inserted in the middle of the sample. A large rubber stopper is pressed into the top of the sample dewar and another dewar in placed inverted over the sample dewar. Steel flanges are added to the top to prevent the assembly from floating. This assembly is lowered into a bath dewar containing propylene glycol. An insulated lid is placed on top, the stirrer is energized and computer control of the heater is initiated. The computer maintains zero temperature difference between the bath and the grout sample. For safety there was an independent shutdown circuit to prevent excessive bath temperature. 
SRNL-STI-2010-00806

Revision 0

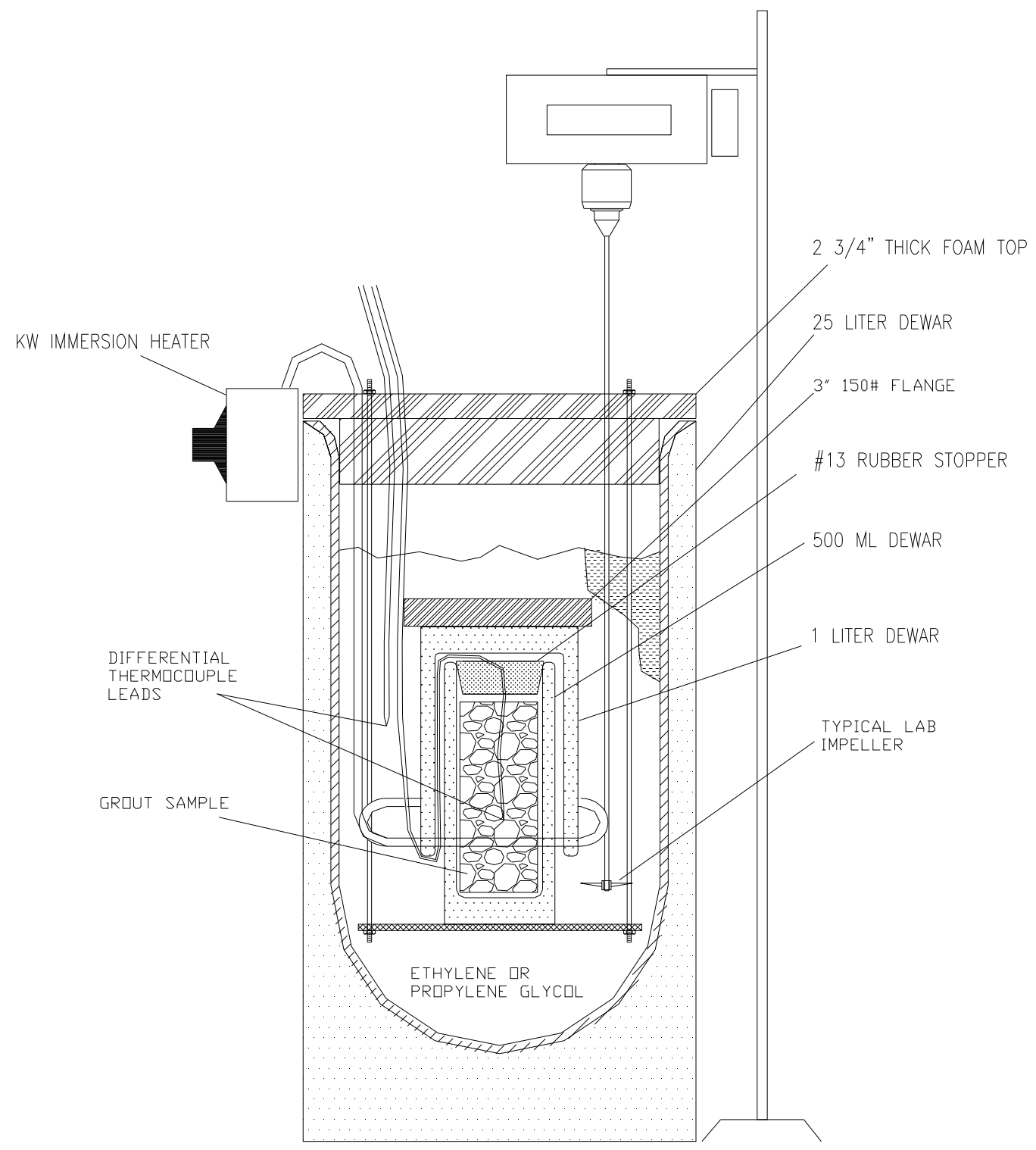

Figure 1 Schematic of Adiabatic Calorimeter

Calorimetry required preparatory steps. First the differential thermocouple was calibrated. Both sides of the differential thermocouple and also the sample thermocouple were placed in a stirred beaker containing propylene glycol at $80^{\circ} \mathrm{C}$, the data $\log$ was started and the temperature was allowed to drift down over a period of hours. Propylene glycol was used instead of water because of its low vapor pressure and instead of ethylene glycol because of its low toxicity. A perfect differential thermocouple would always read zero microvolts regardless of bath temperature. The actual relationship between output signal and bath temperature was curve fit with a quadratic equation and used to correct the signal from the differential thermocouple. Another preparatory step was to place propylene glycol at approximately $80^{\circ} \mathrm{C}$ in the sample container and verify that the temperature held constant for a period of days. A third preparatory step was to place a low 
power electrical heat source, $60 \mathrm{~mW}$, in the sample container and verify that temperature increased at the theoretical rate.

For an actual calorimeter run, a plastic sample release was made from pieces of two $250 \mathrm{~mL}$ polyethylene bottles nested together. This allowed hardened grout to later be easily removed from the sample dewar. Grout materials were mixed to uniform consistency, poured into the sample release and the sample weight measured. The grout in the sample release was inserted in the sample dewar and the sample thermocouple and the sample side of the differential thermocouple were inserted in the middle of the grout sample. The top of the sample dewar was plugged with a rubber stopper and another, larger dewar was inverted and lowered over the sample dewar. The whole assembly was lowered into a much larger dewar containing propylene glycol. The large dewar also contained a stirrer and an electric heating element. The large dewar was closed and the stirrer was energized. Proportional integral differential (PID) control was used to control the heater power to drive the differential temperature error to zero. Proportional control alone is inadequate because there is always a residual temperature offset. The differential term was set to zero.

Heat of hydration increased the temperature of the grout and also the temperature of the sample release, the inner half of the rubber stopper and the inside of the sample dewar, assumed to be equal to half of the sample dewar weight. The additional objects in contact with the grout consumed part of the heat of hydration. To account for this effect the masses of the grout, sample release, stopper and dewar were all measured. The specific heat of the grout was measured as described in the next section of this report. It should be noted that the temperature increase of a massive pour of grout would be greater than the uncorrected temperature increase that was measured in the adiabatic calorimeter because some of the energy released by the grout in the calorimeter, roughly one-third, went to heating the dewar, etc. The equation for heat generation rate follows.

$\mathrm{G}=\frac{\mathrm{dT}}{\mathrm{dt}} \frac{1}{\mathrm{M}_{\mathrm{g}}} \sum_{\mathrm{i}=1}^{\mathrm{n}} \mathrm{M}_{\mathrm{i}} \mathrm{C}_{\mathrm{pi}}$

$\mathrm{i}=$ grout, dewar, stopper, etc.

$\mathrm{G}=$ heat generation rate in $\mathrm{w} / \mathrm{kg}$

$\mathrm{T}=$ temperature in $\mathrm{K}$

$\mathrm{t}=$ time in seconds

$\mathrm{M}=$ mass in $\mathrm{kg}$, subscript $\mathrm{g}$ denotes grout

$\mathrm{C}_{\mathrm{p}}=$ specific heat in $\mathrm{J} / \mathrm{kg}-\mathrm{K}$

\subsection{Measurement of Specific Heat}

A sample of grout was broken and pieces with sizes ranging from 0.125 " to 0.25 " were selected. The sample was weighed and its temperature measured. Also, some ethylene glycol was heated to about $80^{\circ} \mathrm{C}$, poured into a tared dewar and the dewar was reweighed. The glycol temperature was remeasured, the grout poured in, a thermocouple was inserted and the mixture gently agitated and the mixture temperature measured. Grout specific heat was calculated using the following equation, where $M_{e}$ and $M_{g}$ are the masses of ethylene glycol and grout and $T_{e}, T_{g}$ and $T_{m}$ are the temperatures of ethylene glycol, grout and mixture.

$$
C_{g}=\frac{M_{e} C_{e}\left(T_{m}-T_{e}\right)}{M_{g}\left(T_{g}-T_{m}\right)}
$$


2.3 Measurement of Density and Thermal Conductivity

A plastic mold was used to cast a 2" x 2" cylinder of grout. The mold included a 1/16" rod that terminated at the center of the cylinder. The cylinder was weighed and its volume was calculated to give volume. Density is equal to mass divided by volume.

Thermal conductivity was determined by cementing a 1/16" thermocouple in the hole and painting the outer surface of the cylinder to waterproof it. The thermocouple was connected to a data acquisition system and the grout cylinder was immersed in a beaker of boiling water. The textbook Handbook of Heat Transfer Fundamentals by Rohsenow, Hartnett and Ganić [1985] contains a theoretical solution for transient heat transfer in a cylinder having height equal to diameter and for large heat transfer coefficient at the surface. Curve $f$ in Figure 2 shows that normalized temperature response at the center of the cylinder is a function of normalized time. Normalized temperature is equal to centerline temperature minus initial temperature divided by the quantity surface temperature minus initial temperature. Normalized time is equal to time multiplied by thermal diffusivity and divided by radius squared. Trial and error was used to find a value of thermal diffusivity to make the transient data most closely match Curve $f$. Thermal diffusivity is equal to thermal conductivity divided by density and specific heat. Since both density and specific heat were independently measured, thermal conductivity was then calculated.

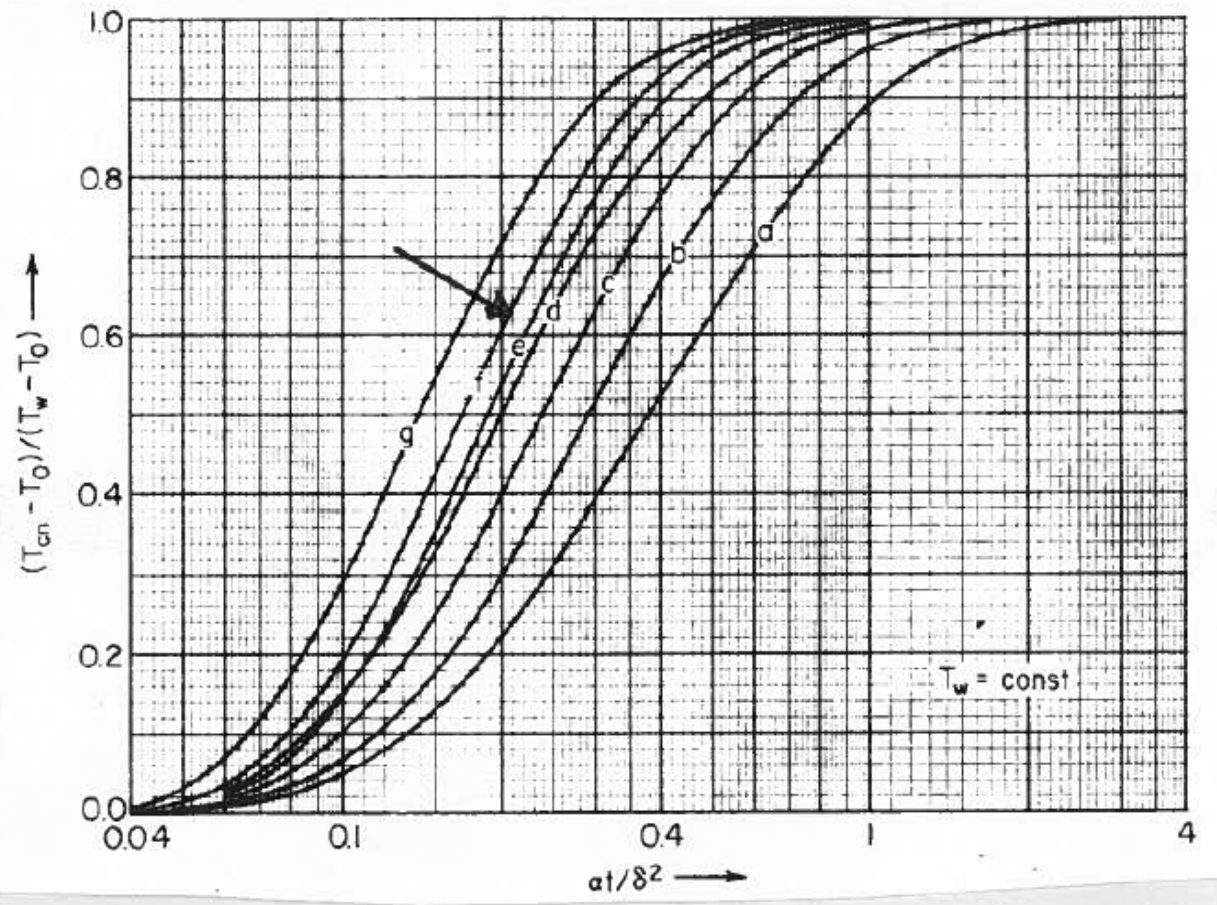

Figure 2 Transient Thermal Response of Short Cylinder

\subsection{Results and Discussion}

\subsection{Reactor Grouts Tested}

Two basic types of reactor grouts were tested, grouts containing magnesium potassium phosphate cement and grouts containing calcium sulfo-aluminate cement. The magnesium potassium phosphate (MKP) grouts were divided into grouts containing pre-mixed Bindan Monogrout and grouts in which magnesium oxide $(\mathrm{MgO})$ and mono potassium phosphate (monoKP) were added 
separately. The formulations of all reactor grouts are listed in Tables 1,2 and 3 in terms of weight percentages. The names ANL-1 and RG-18 refer to the same composition. The listing of two starting dates for one composition means that the composition was tested twice in a calorimeter. Either the first calorimeter run was interrupted or the first result was unexpected.

Table 1 Formulations of Magnesium Potassium Phosphate Grouts

\begin{tabular}{|l|r|r|r|r|r|r|r|r|}
\hline $\begin{array}{l}\text { Calorimeter start } \\
\text { dates }\end{array}$ & $\begin{array}{r}11 / 13 / 09 \\
11 / 19 / 09\end{array}$ & $4 / 26 / 10$ & $5 / 13 / 10$ & $7 / 27 / 10$ & $9 / 28 / 09$ & $11 / 4 / 09$ & $11 / 9 / 09$ & $5 / 26 / 10$ \\
\hline designation & $\begin{array}{r}\text { ANL-1 } \\
\text { aka RG-18 }\end{array}$ & ANL-2 & ANL-3 & ANL-4 & RG-1 & RG-2 & RG-3 & $40 \mathrm{H}$ \\
& 5.38 & 5.22 & 3.81 & 3.98 & 8.93 & 2.68 & 3.57 & 3.16 \\
\hline MgO & 18.15 & 17.61 & 12.85 & 13.41 & 30.52 & 9.17 & 12.23 & 10.69 \\
monoKP (KH2PO4) & 54.89 & 53.26 & 33.29 & 20.84 & 0.00 & 0.00 & 0.00 & 0 \\
Fly ash Class C & 0.00 & 0.00 & 0.00 & 0.00 & 39.45 & 81.86 & 75.81 & 19.04 \\
Fly ash Class F & 0.00 & 0.00 & 33.29 & 48.63 & 0.00 & 0.00 & 0.00 & 53.66 \\
Sand & 0.00 & 0.00 & 0.00 & 0.00 & 0.00 & 0.00 & 0.00 & 0 \\
Bauxite & 0.00 & 0.00 & 0.00 & 0.00 & 0.00 & 0.00 & 0.00 & 0.14 \\
KIM 301 & 1.19 & 1.16 & 1.28 & 0.89 & 0.00 & 0.00 & 0.00 & 0.28 \\
Boric acid & 20.39 & 22.75 & 15.50 & 12.25 & 21.10 & 6.29 & 8.38 & 13.04 \\
Water & 100.00 & 100.00 & 100.00 & 100.00 & 100.00 & 100.00 & 100.00 & 100.00 \\
total & $>98$ & $>211$ & 201 & 200 & 286 & 96 & 138 & 149 \\
\hline Heat of hydration, & $>182$ & & & & & & & \\
J/mL & $>43$ & $>73$ & 94 & 93 & 103 & 41 & 59 & 61 \\
& $>80$ & & & & & & \\
\hline Adiabatic & & & & & & \\
temperature & & & & & & & \\
increase, ${ }^{\circ} \mathrm{C}$ & & & & & & & \\
\hline
\end{tabular}

Table 2 Formulations of Pre-mixed (Bindan) Grouts

\begin{tabular}{|l|r|r|r|r|r|r|r|}
\hline Calorimeter start dates & $11 / 24 / 09$ & & & & & & \\
& $11 / 26 / 09$ & $3 / 24 / 10$ & $4 / 14 / 10$ & $4 / 14 / 10$ & $4 / 30 / 10$ & $5 / 4 / 10$ & $5 / 10 / 10$ \\
\hline designation & BM-1 & $2 \mathrm{H}$ & $12 \mathrm{H} 1$ & $13 \mathrm{H} 1$ & $28 \mathrm{H}$ & $29 \mathrm{H}$ & $32 \mathrm{H}$ \\
\hline Bindan Monogrout SR1.0 & 78.13 & 0.000 & 0.00 & 0.00 & 0.00 & 0.00 & 0.00 \\
Bindan Monogrout SR3.10 & 0.00 & 85.47 & 0.00 & 0.00 & 0.00 & 0.00 & 0.00 \\
SR3.10 binder only & 0.00 & 0.00 & 13.89 & 13.89 & 17.51 & 15.76 & 14.01 \\
Fly ash Class F & 7.81 & 0.00 & 17.40 & 17.40 & 17.51 & 19.13 & 19.13 \\
Sand & 0.00 & 0.00 & 55.60 & 27.80 & 52.54 & 52.17 & 53.91 \\
Bauxite & 0.00 & 0.00 & 0.00 & 27.80 & 0.00 & 0.00 & 0.00 \\
KIM 301 & 0.00 & 0.00 & 0.10 & 0.10 & 0.18 & 0.87 & 0.87 \\
Boric acid & 0.00 & 0.00 & 0.00 & 0.00 & 0.00 & 0.00 & 0.00 \\
Water & 14.06 & 14.53 & 13.00 & 13.00 & 12.26 & 12.17 & 12.17 \\
total & 100.00 & 100.00 & 100.00 & 100.00 & 100.00 & 100.00 & 100.00 \\
\hline Heat of hydration, J/mL & $>191$ & 178 & & & & & \\
& 216 & & 139 & 142 & 197 & 163 & 155 \\
\hline Adiabatic temperature & $>78$ & 73 & 50 & 52 & 72 & 59 & 64 \\
increase, ${ }^{\circ} \mathrm{C}$ & 88 & & & & & & \\
\hline
\end{tabular}


Table 3 Formulations of Calcium Alumino-sulfate Grouts

\begin{tabular}{|c|c|c|c|c|c|c|}
\hline \multirow[t]{2}{*}{ Calorimeter start dates } & $9 / 16 / 10$ & $10 / 1 / 10$ & $10 / 7 / 10$ & $7 / 29 / 10$ & $\begin{array}{l}9 / 10 / 10 \\
9 / 16 / 10 \\
\end{array}$ & $9 / 14 / 10$ \\
\hline & $101 \mathrm{H}$ & $102 \mathrm{H}$ & $103 \mathrm{H}$ & FG9-26H & $\mathrm{T} 12-1$ & T4-18 \\
\hline Ciment Fondu & 4.61 & 9.06 & 4.61 & 8.32 & 9.07 & 4.61 \\
\hline Plaster of Paris & 2.30 & 4.53 & 2.30 & 4.17 & 4.50 & 2.30 \\
\hline Sand & 55.30 & 51.56 & 55.28 & 55.45 & 51.55 & 55.30 \\
\hline Fly ash Class F & 17.98 & 15.32 & 17.97 & 13.89 & 15.34 & 17.98 \\
\hline KIM 301 & 0.14 & 0.14 & 0.14 & 0.00 & 0.14 & 0.14 \\
\hline Diutan gum & 0.02 & 0.02 & 0.02 & 0.02 & 0.02 & 0.02 \\
\hline SIKA 2100 & 0.09 & 0.09 & 0.09 & 0.09 & 0.09 & 0.09 \\
\hline Boric acid & 0.05 & 0.10 & 0.09 & 0.00 & 0.10 & 0.05 \\
\hline Water & 19.51 & 19.18 & 19.51 & 18.05 & 19.19 & 19.51 \\
\hline total & 100.00 & 100.00 & 100.00 & 100.00 & 100.00 & 100.00 \\
\hline heat of hydration, $\mathrm{J} / \mathrm{mL}$ & 69 & 130 & 54 & 101 & 130 & 62 \\
\hline & & & & & 124 & \\
\hline Adiabatic temperature & 26 & 54 & 24 & 47 & 52 & 25 \\
\hline increase, ${ }^{\circ} \mathrm{C}$ & & & & & 50 & \\
\hline
\end{tabular}

Here are notes on components of the formulations.

1. In some grouts boric acid was added to retard setting.

2. Class F fly ash has a relatively low heat of hydration $194 \mathrm{~J} / \mathrm{g}$, while Class $\mathrm{C}$ fly ash has a larger heat of hydration $437 \mathrm{~J} / \mathrm{g}$ [Schindler and Folliard, 2003].

3. Sand and bauxite are fillers having no heat of hydration.

4. Plaster of Paris is calcium sulfate hemi-hydrate.

5. Ciment Fondu from Kerneos Aluminate Technologies is a calcium aluminate cement.

6. KIM from Kryton, Inc. is an integral water proofing admixture.

7. SIKA Viscocrete 2100 from W. R. Grace, Inc. provides greater grout plasticity at lower water contents.

8. Diutan gum from C. P. Kelco decreases water bleeding and increases grout uniformity.

3.2 Results for Density, Thermal Conductivity and Specific Heat

Results are listed in Table 4. Densities are all approximately $2 \mathrm{~g} / \mathrm{mL}$ which is reasonable considering the components. Specific heats range from $0.23 \mathrm{cal} / \mathrm{g}-\mathrm{K}$ to $0.35 \mathrm{cal} / \mathrm{g}-\mathrm{K}$. Thermal conductivity was the most variable property measured with values ranging from $0.45 \mathrm{~W} / \mathrm{m}-\mathrm{K}$ to $2.1 \mathrm{~W} / \mathrm{m}-\mathrm{K}$. 
Table $4 \quad$ Summary of Results

\begin{tabular}{|c|c|c|c|c|c|c|c|c|c|}
\hline Grout & Description & $\begin{array}{l}\text { Date } \\
\text { calorimeter } \\
\text { started }\end{array}$ & End date & $\begin{array}{c}\text { Initial } \\
\text { temp. } \\
\text { C }\end{array}$ & Days & $\begin{array}{c}\text { Calorimeter } \\
\quad \#\end{array}$ & $\begin{array}{l}\text { Density, } \\
\mathrm{g} / \mathrm{mL}\end{array}$ & $\begin{array}{c}\text { Specific } \\
\text { heat, } \\
\mathrm{C}_{\mathrm{p}} \\
\mathrm{cal} / \mathrm{g}-\mathrm{K}\end{array}$ & $\begin{array}{l}\text { Thermal } \\
\text { Cond, k } \\
\text { W/m-K }\end{array}$ \\
\hline RG-1 & Base Ceramicrete: $50 \%$ ceramicrete, $50 \%$ fly ash & $9 / 28 / 2009$ & $10 / 5 / 2009$ & 24 & 7 & 1 & 1.879 & 0.352 & 0.45 \\
\hline RG-2 & $15 \%$ Ceramicrete, $85 \%$ fly ash & $11 / 4 / 2009$ & $11 / 5 / 2009$ & 24 & 1 & 1 & & & \\
\hline RG-3 & $20 \%$ Ceramicrete, $80 \%$ fly ash & $11 / 9 / 2009$ & $11 / 11 / 2009$ & 24 & 2 & 1 & & & \\
\hline RG-18 & ANL recipe, $70 \%$ fly ash C, $30 \%$ ceram. $+1.5 \%$ boric acid & $11 / 13 / 2009$ & $11 / 18 / 2009$ & 25 & 5 & 1 & 1.858 & 0.293 & \\
\hline RG-18R & ANL recipe, $70 \%$ fly ash $\mathrm{C}, 30 \%$ ceram. $+1.5 \%$ boric acid & $11 / 19 / 2009$ & $11 / 23 / 2009$ & 21 & 4 & 1 & 1.858 & 0.293 & \\
\hline $\mathrm{BM}-1$ & Bindan Monogrout $78 \%$, Class $\mathrm{F}$ flyash $8 \%$, water & $11 / 24 / 2009$ & $11 / 25 / 2009$ & 18 & 1 & 2 & & 0.279 & 1.85 \\
\hline $\mathrm{BM}-1 \mathrm{R}$ & Bindan Monogrout $78 \%$, Class $\mathrm{F}$ flyash $8 \%$, water & $11 / 26 / 2009$ & $11 / 30 / 2009$ & 18 & 4 & 2 & & 0.279 & 1.85 \\
\hline $2 \mathrm{H}$ & Bindan Monogrout & $3 / 24 / 10$ & $3 / 29 / 10$ & 23 & 5 & 2 & & & \\
\hline $12 \mathrm{H} 1$ & $\begin{array}{l}\text { Monogrout } 13.9 \text {, sand } 55.6 \text {, fly ash } \mathrm{F} 17.4, \mathrm{KIM} 0.1 \text {, water } \\
13.0\end{array}$ & $4 / 14 / 2010$ & $4 / 16 / 2010$ & 21 & 2 & 1 & & & \\
\hline $13 \mathrm{H} 1$ & $\begin{array}{l}\text { Monogrout } 13.9 \text {, sand } 27.8 \text {, bauxite } 27.8 \text {, fly ash F } 17.4 \text {, KIM } \\
0.1 \text {, water } 13.0\end{array}$ & $4 / 14 / 2010$ & $4 / 16 / 2010$ & 22 & 2 & 2 & & & \\
\hline $28 \mathrm{H}$ & monogrout 20 , sand 60 , flyash F 20 & $4 / 30 / 2010$ & $5 / 4 / 2010$ & 22 & 5 & 1 & 2.08 & 0.315 & 1.95 \\
\hline $29 \mathrm{H}$ & monogrout 18 , sand 60 , flyash $\mathrm{F} 22$ & $5 / 4 / 2010$ & $5 / 10 / 2010$ & 23 & 5 & 1 & 2.08 & 0.316 & 2.1 \\
\hline $32 \mathrm{H}$ & monogrout 16 , sand 62 , flyash F 22 & $5 / 10 / 2010$ & $5 / 14 / 2010$ & 25 & 4 & 1 & 2.10 & 0.275 & 1.9 \\
\hline $40 \mathrm{H}$ & monogrout 16 , sand 62 , flyash F 22 & $5 / 26 / 2010$ & $6 / 7 / 2010$ & 21 & 11 & 1 & 2.11 & 0.277 & 1.75 \\
\hline ANL-2 & boric acid, $\mathrm{MgO}, \mathrm{KH} 2 \mathrm{PO} 4$, flyash $\mathrm{C}$ & $4 / 26 / 2010$ & $5 / 10 / 2010$ & 19 & 14 & 2 & 2.175 & 0.317 & 0.7 \\
\hline ANL-3 & boric acid, $\mathrm{MgO}, \mathrm{KH} 2 \mathrm{PO} 4$, flyash $\mathrm{C}$ & $5 / 13 / 2010$ & $6 / 10 / 2010$ & 20 & 18 & 2 & 2.01 & 0.253 & 1.05 \\
\hline ANL-4 & boric acid, $\mathrm{MgO}, \mathrm{KH} 2 \mathrm{PO} 4$, flyash $\mathrm{C}$ & $7 / 27 / 2010$ & $8 / 30 / 2010$ & 23 & 33 & 2 & 2.15 & 0.238 & 1.45 \\
\hline FG9-26H & sand, ash, Plaster of Paris & $7 / 29 / 2010$ & $8 / 2 / 2010$ & 23 & 4 & 1 & 1.922 & 0.27 & 1.4 \\
\hline T12-1 & Fondu, sand, ash, Plaster of Paris & $9 / 10 / 2010$ & $9 / 13 / 2010$ & 22 & 3 & 2 & & & \\
\hline $\mathrm{T} 4-18 \mathrm{H}$ & Fondu, sand, ash, Plaster of Paris & $9 / 14 / 2010$ & $9 / 16 / 2010$ & 25 & 2 & 2 & & & \\
\hline $\mathrm{T} 12-1 \mathrm{R}$ & Fondu, sand, ash, Plaster of Paris & $9 / 16 / 2010$ & $9 / 20 / 2010$ & 24 & 4 & 2 & & & \\
\hline $101 \mathrm{H}$ & Fondu, sand, ash, Plaster of Paris & $9 / 16 / 2010$ & $10 / 1 / 2010$ & 23 & 15 & 2 & 1.92 & 0.332 & 1.6 \\
\hline $102 \mathrm{H}$ & Fondu, sand, ash, Plaster of Paris & $10 / 1 / 2010$ & $10 / 3 / 2010$ & 23 & 2 & 2 & 1.97 & 0.294 & 1.5 \\
\hline $103 \mathrm{H}$ & Fondu, sand, ash, Plaster of Paris & $10 / 7 / 2010$ & $1011 / 2010$ & 26 & 4 & 1 & 1.96 & 0.325 & 1.6 \\
\hline
\end{tabular}




\subsection{Results for Heat of Hydration}

Adiabatic calorimeter results are plotted for Magnesium Mono-Potassium Phosphate (MKP) grout formulations originating from Argonne National Laboratory (ANL), Pre-mixed MKP (Bindan) grouts and Calcium Sulfo-Aluminate cement in Figures 3, 4 and 5, respectively. Calorimeter runs were ended when steady state, or close to it, had been achieved. Some runs ended early because of hardware problems. Other runs were ended when it became clear that the formulation was unacceptable because of very long set time. The suffix $\mathrm{R}$ denotes a repeat calorimeter run. The first derivatives of temperature for grouts $101 \mathrm{H}$ and $102 \mathrm{H}$ were used to compute heat generation rates which are plotted in Figure 6. Heats of hydration in joules per $\mathrm{mL}$ and adiabatic temperature increases are listed in Tables 1,2 and 3. The following observations are made.

1. Calorimeter reproducibility was good. The repeated runs BM-1 and BM-1R were very similar. Runs T12-1 and T12-1R had the same adiabatic temperature increase and the shapes of the curves were the same, but T12-1R proceeded faster because it had a higher initial temperature.

2. Boric acid acted as a set retardant, delaying achievement of final temperature to as much as 600 hours. In general, higher concentrations of boric acid increased the time required to achieve set. The concentration of boric acid does not seem to affect the final temperature increase. There was an apparent exception to the rule that set retardation is proportional to concentration of boric acid. Figure 4 shows that grouts ANL-3 and ANL4 with $1.25 \%$ and $0.89 \%$ boric acid were retarded more than ANL-1, ANL-1R and ANL2 with $1.19 \%$ boric acid. However, the grouts are not fully comparable because most of the Class C fly ash in grout ANL-1, etc. was replaced with sand in grouts ANL-3 and ANL-4.

3. Figure 6 shows that the retarding effect may be non-linear. Doubling the concentration of boric acid quadruples the time of maximum heat generation.

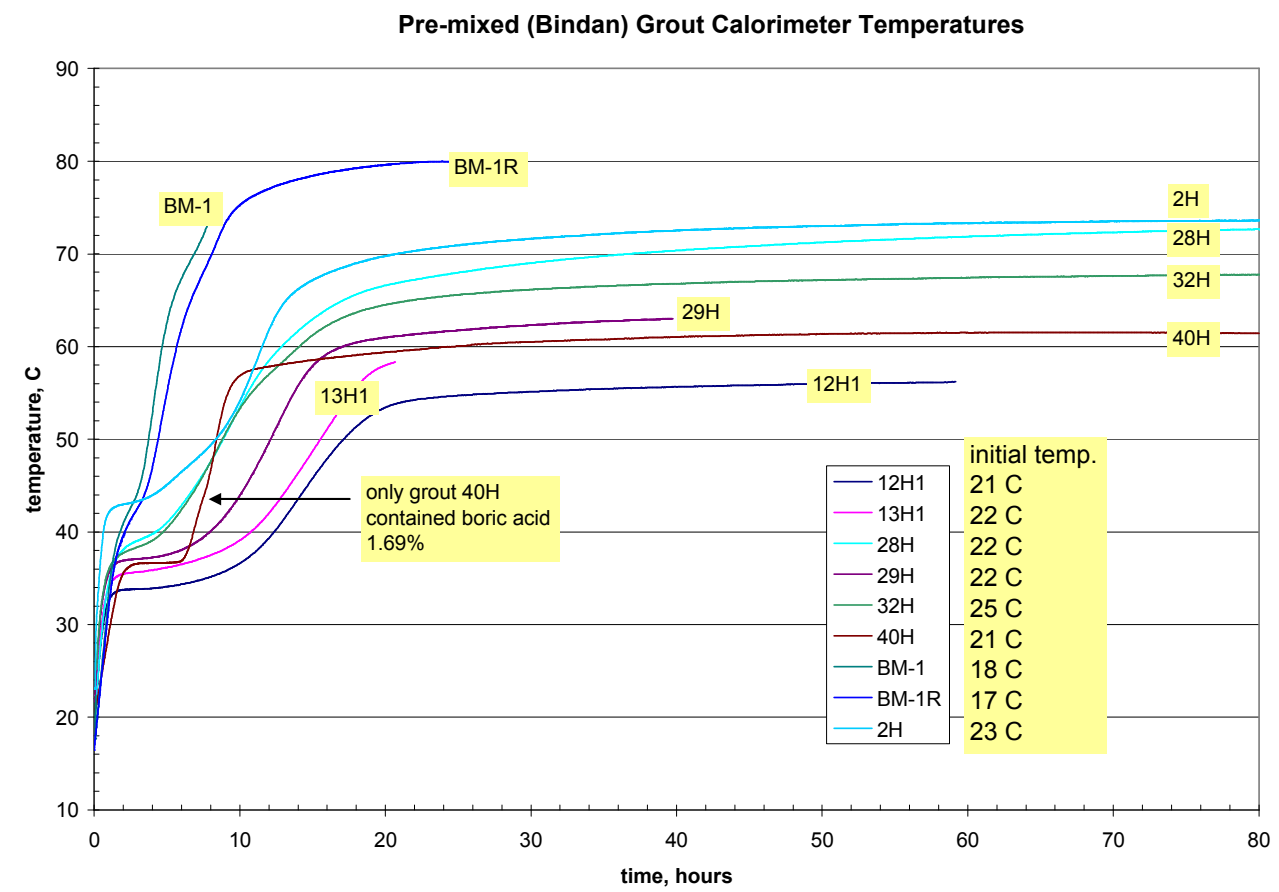

Figure 3 Calorimeter Temperatures for Pre-mixed MKP (Bindan) Grout 
SRNL-STI-2010-00806

Revision 0

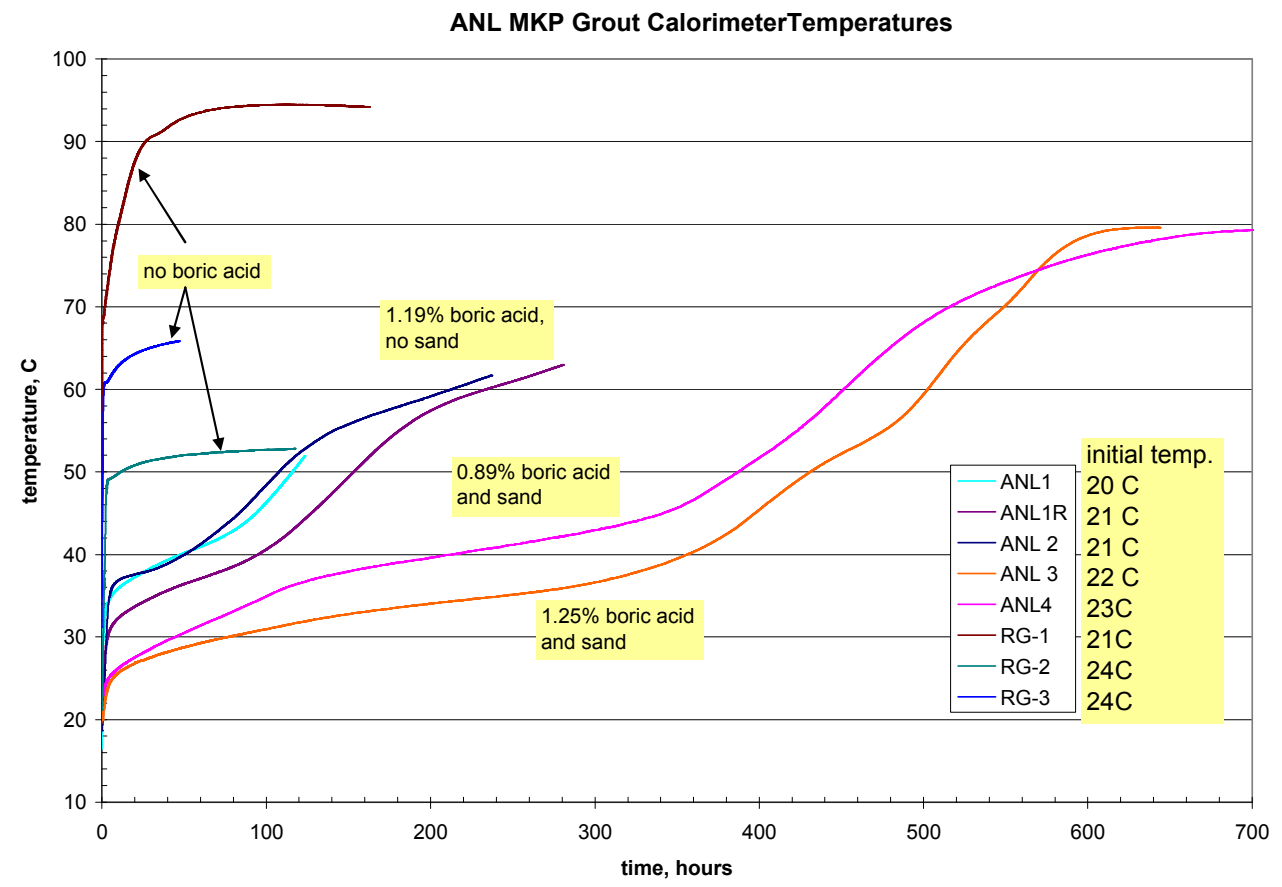

Figure 4 Calorimeter Temperatures for ANL MKP Grouts

Calcium Sulfo-Aluminate Grout Calorimeter Temperatures

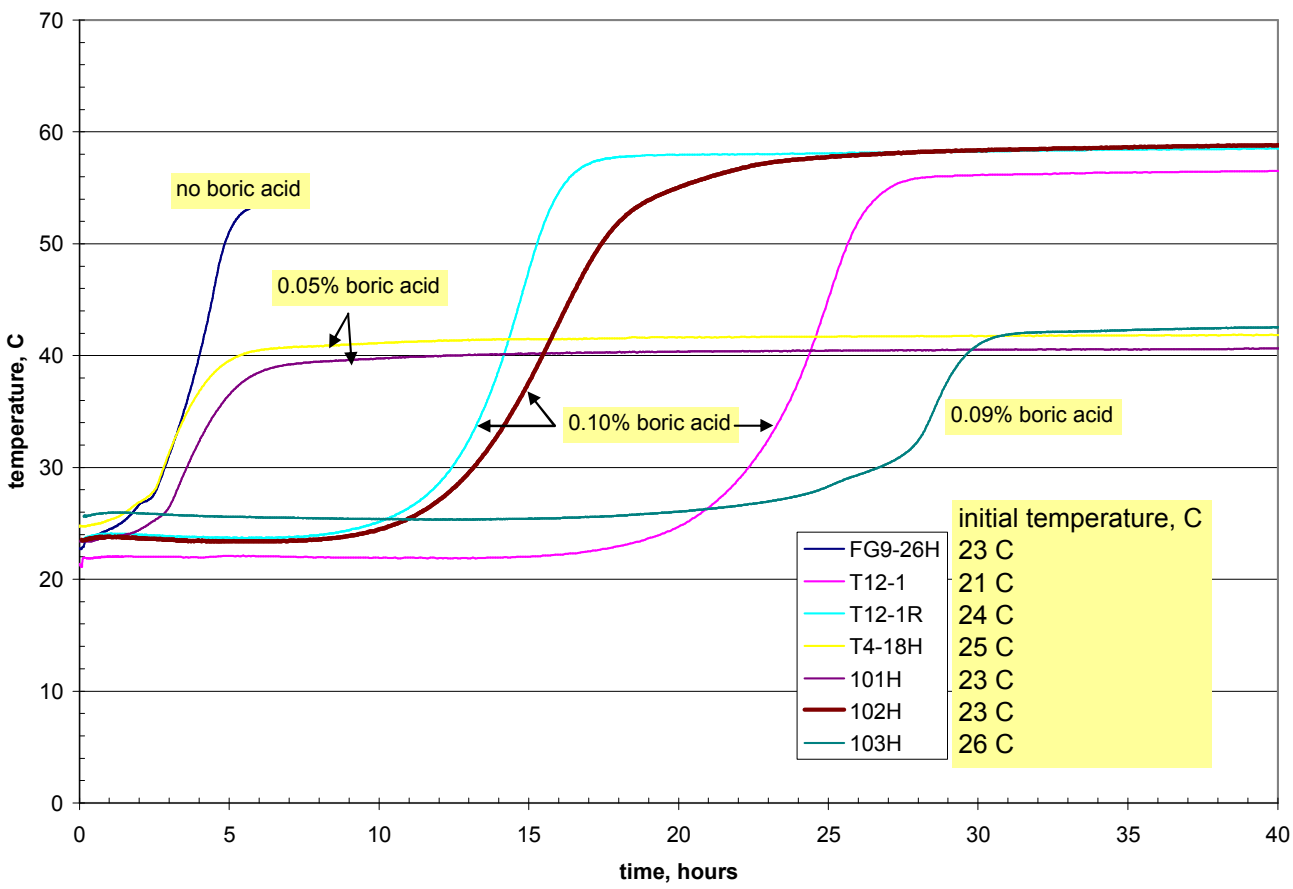

Figure 5 Calorimeter Temperatures for Calcium Sulfo-aluminate Grouts 


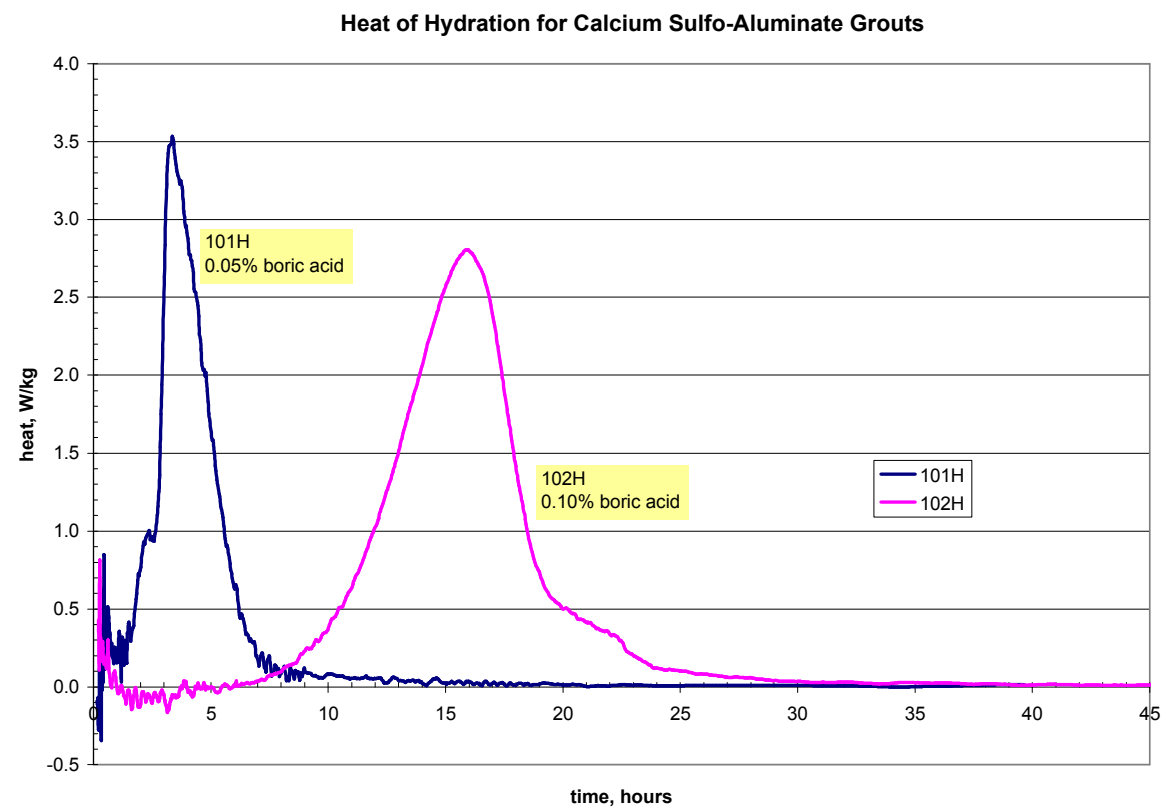

Figure 6 Heat Generation for Calcium Sulfo-Aluminate Grouts

Figures 7, 8 and 9 plot the total heat of hydration vs. concentration of binder. Heat of hydration was generally proportional to concentration of binder. Figure 7 shows that ANL MKP grouts that included sand in the formulation had relatively larger heats of hydration than for grouts that included no sand and more fly ash. This seems counterintuitive since fly ash has a heat of hydration and sand does not. The answer may be that there was insufficient water to fully hydrate the binder. Fly ash consumed some of the water but sand did not. 
SRNL-STI-2010-00806

Revision 0

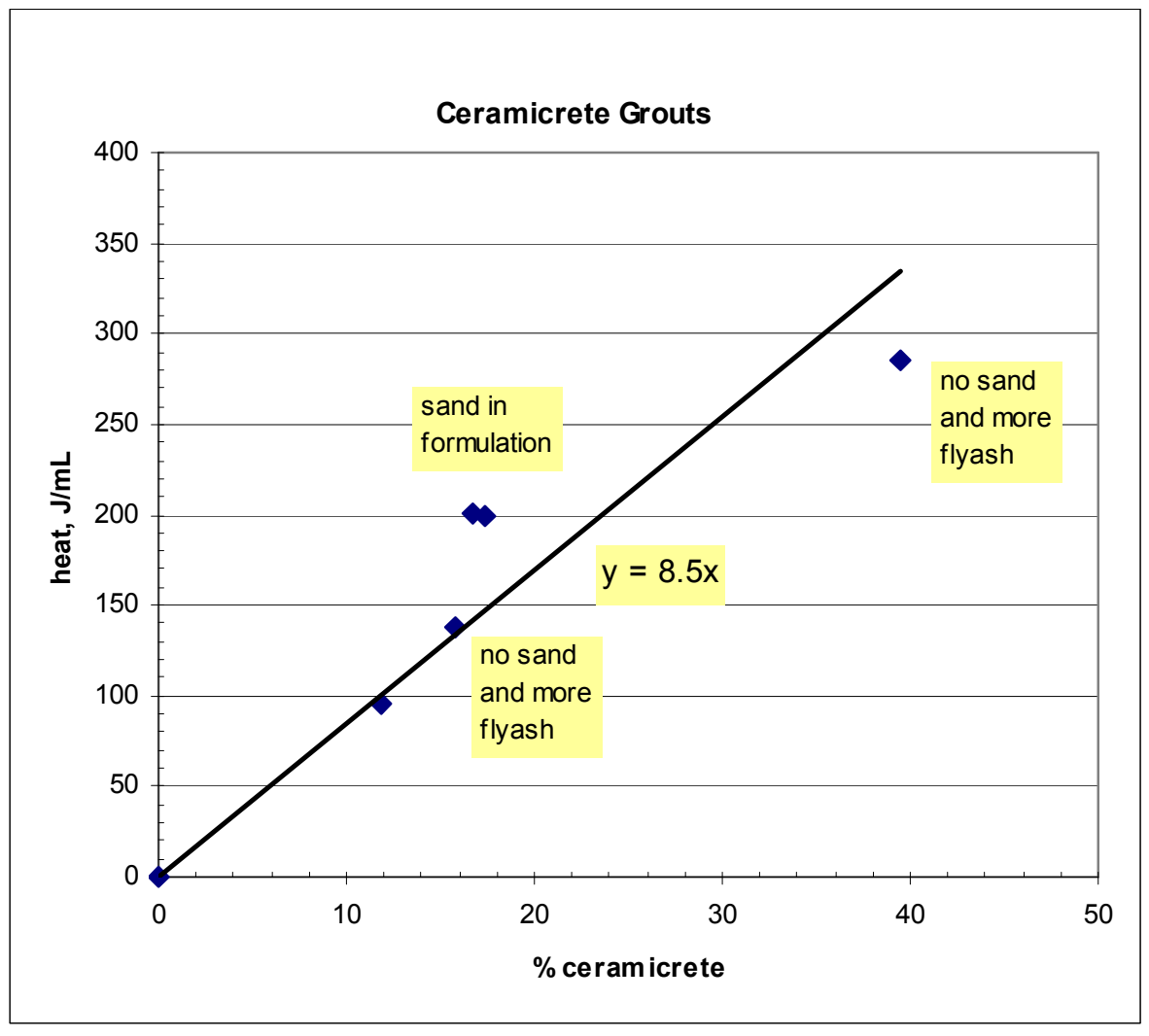

Figure $7 \quad$ Heat of Hydration for ANL MKP Grouts

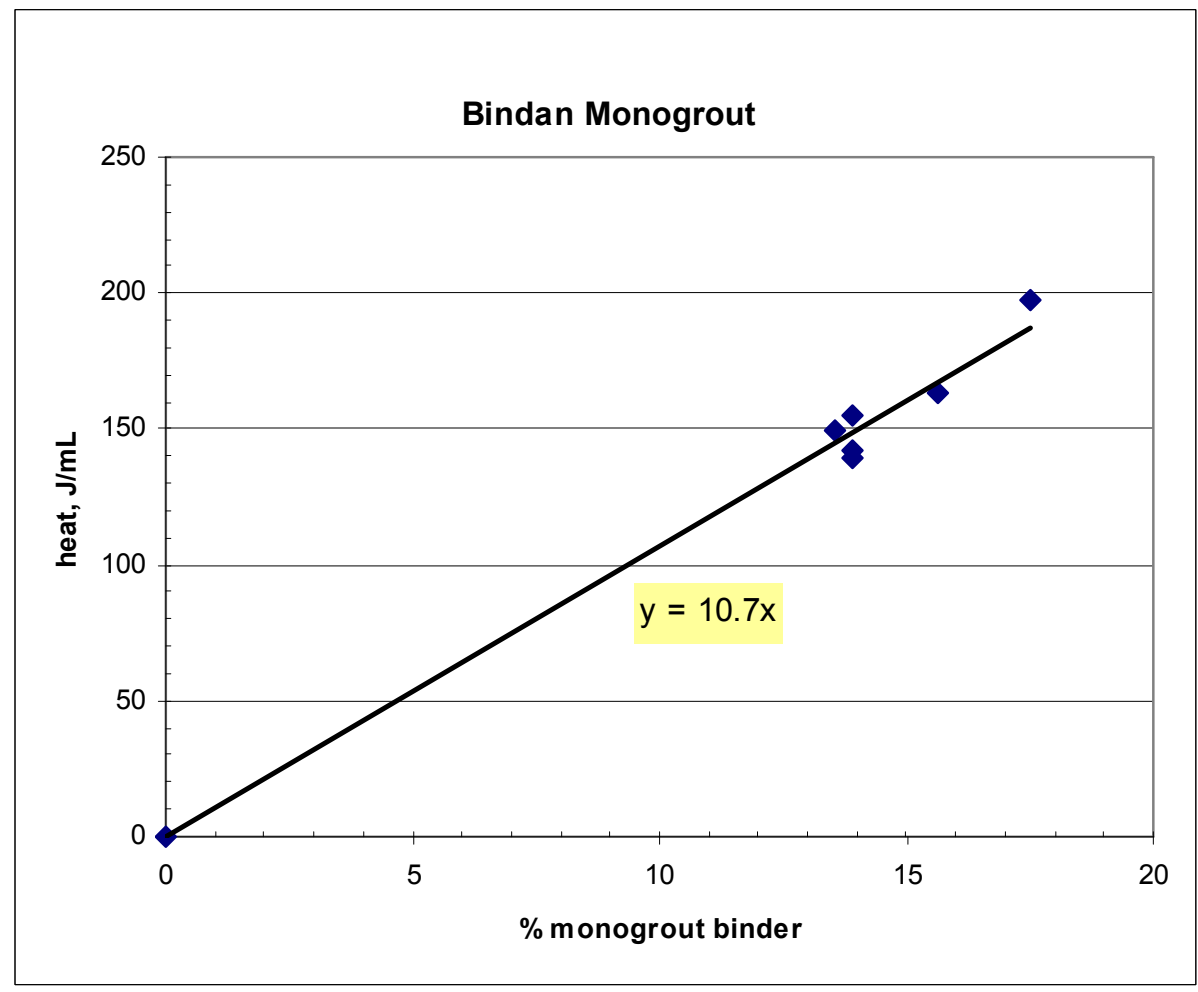

Figure 8 Heat of Hydration for Pre-mixed Bindan Formulations 
SRNL-STI-2010-00806

Revision 0

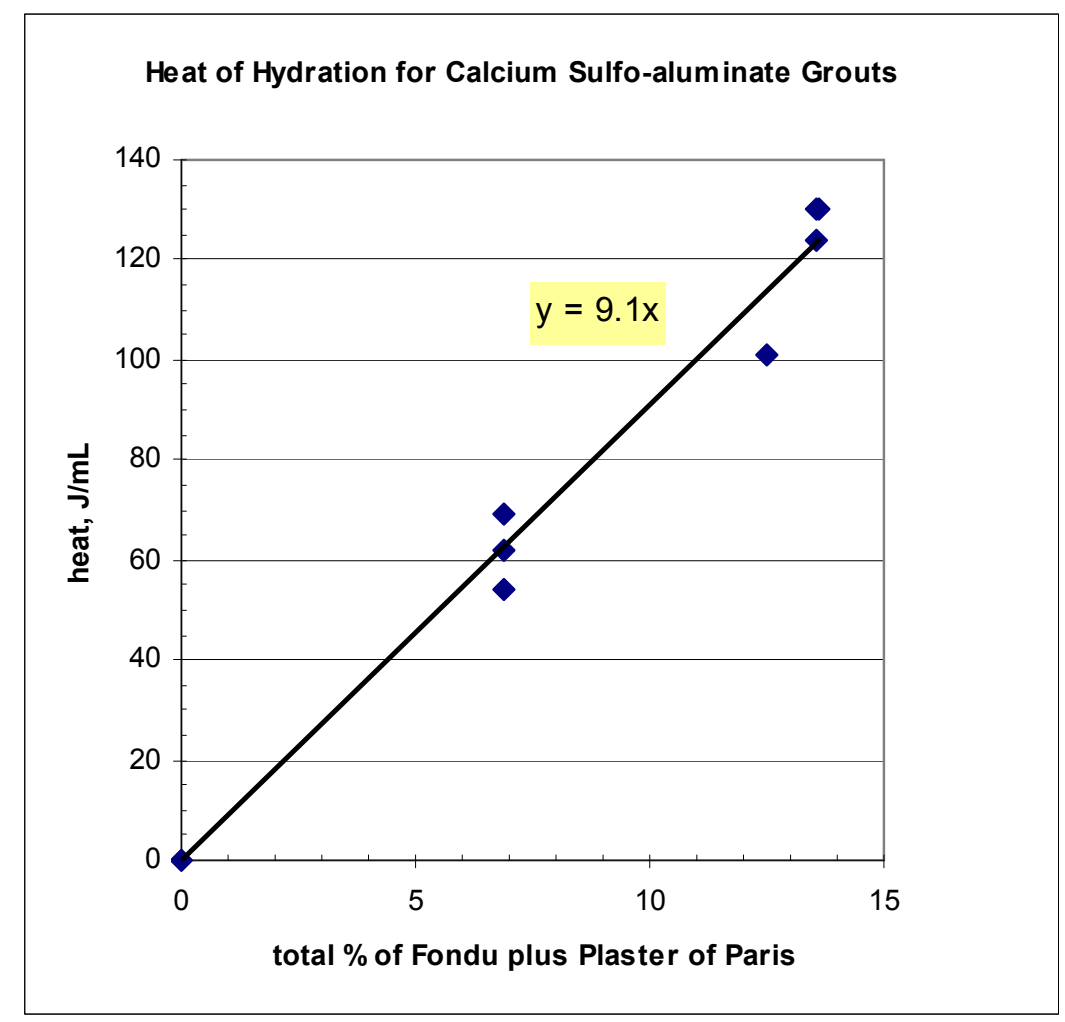

Figure 9 Heat of Hydration for Calcium Sulfo-aluminate Grouts

\subsection{Conclusions}

The Calcium Sulfo-Aluminate reactor grout called $102 \mathrm{H}$ in this report satisfied the requirements described in the Introduction of this report. This composition afforded about ten hours of working time. Heat release began at 12 hours and was complete by 24 hours. The adiabatic temperature rise was $54^{\circ} \mathrm{C}$ which was within specification. The final product was hard and displayed no visible segregation. The density and maximum particle size were within specification.

\subsection{Recommendations, Path Forward or Future Work}

No further work is planned for testing reactor area grouts. However, if future adiabatic calorimetry work is anticipated, the calorimeters should be moved to a location with better temperature control. Large temperature variations, $10^{\circ} \mathrm{C}$ to $27^{\circ} \mathrm{C}$ or $50^{\circ} \mathrm{F}$ to $80^{\circ} \mathrm{F}$, have been observed in the room in 786-A where the calorimeters are now located. Twice on very cold days the control computer malfunctioned.

\subsection{References}

B. Fogle, M. Collins, H. Guerrero, Grout Temperature Measurement in 105-R Disassembly Basin D\&E Canal," SRNL-TR-2010-00098", April 22, 2010. 
H. Guerrero, Z. Qureshi, M. Restivo, and J. Steimke, "Measurements of Thermo-Physical Properties of Base Portland Cement and Ceramicrete Grouts", SRNL-L3100-2009-00266, October 29, 2009.

C. A. Langton, et al., "Use of Cementitious Materials for SRS Reactor Facility In-Situ Decommissioning”, SRNL-STI-2010-00712.

A. K. Schindler and K. J. Folliard, "Influence of Supplementary Cementing Materials on the Heat of Hydration of Concrete", Advances in Cement and Concrete IX Conference, August 2003.

W. M. Rohsenow, J. P. Hartnett and E. N. Ganić, Handbook of Heat Transfer Fundamentals, 1985 .

J. L. Steimke and M. D. Fowley, "Measurement of Thermal Properties of Saltstone", WSRC-TR97-00357, May 1998. 


\section{Distribution:}
A. B. Barnes, 999-W
D. A. Crowley, 773-43A
S. D. Fink, 773-A
B. J. Giddings, 786-5A
C. C. Herman, 999-W
S. L. Marra, 773-A
A. M. Murray, 773-A
F. M. Pennebaker, 773-42A
W. R. Wilmarth, 773-A
C. A. Langton, 773-43A
D. B. Stefanko, 773-43A 